\title{
Megemlékezés
}

\section{EMLÉKEK ÉS GONDOLATOK A MAGYARÓVÁRI AGRÁR-FELSŐOKTATÁS BICENTENÁRIUMÁN ${ }^{1}$}

\section{MEMORIES AND THOUGHTS ON THE BICENTENARY OF AGRICULTURAL HIGHER EDUCATION AT MAGYARÓVÁR}

\author{
Horváth József \\ az MTA rendes tagja, professor emeritus, Pannon Egyetem Georgikon Kar, Növényvédelmi Intézet, Keszthely \\ hor11895@mail.iif.hu, ppi@georgikon.hu
}

„Az egyetemet nem a néma falak, hanem a tanárok szellemi ereje alapítja meg jó hírnevében, áldásos müködésben." (Berde Áron, 1819-1892)

\begin{abstract}
ÖSSZEFOGLALÁS
Magyarországon az 1818-ban alapított Magyaróvári Gazdasági Felsőbb Magántanintézet és későbbi jogutódja, a Magyaróvári Gazdasági Akadémia, jelenleg pedig a győri Széchenyi István Egyetem Mezőgazdaság- és Élelmiszertudományi Kara 2018. október 25-én ünnepélyes tanácsüléssel és obeliszkavatással ünnepelte fennállásának 200. évfordulóját. A szerző az alapítókra, a "nagy tanári karra", a fénykorszakra és azokra a professzorokra is emlékezett, akik több mint fél évszázadon át nemcsak kortársai, barátai, hanem a két évszázados hírnév megőrzői is voltak. Az emlékek közül kiemelte azt is, hogy az európai agrároktatás és agrárkutatás sikertörténetében a Pannon Egyetem három dunántúli kampusza (Keszthely, Mosonmagyaróvár, Kaposvár) és a gödöllői Szent István Egyetem közösen osztozott a sikerekben és osztozik az emlékekben is.
\end{abstract}

\section{ABSTRACT}

The Magyaróvár Private Agricultural Higher School (founded in 1818) - later Magyaróvár Agricultural Academy - today Faculty of Agricultural and Food Sciences Széchenyi István University, Mosónmagyaróvár celebrated its $200^{\text {th }}$ anniversary with a ceremonious council meeting on the

${ }^{1}$ Az 1818. október 25-én alapított Magyaróvári Gazdasági Felsőbb Tanintézet 200. évfordulója alkalmából a győri Széchenyi István Egyetem Mezőgazdaság- és Élelmiszertudományi Kar Tanévnyitó Ünnepi ülésére (Mosonmagyaróvár, 2018. október 25.) írott beszéd szerkesztett változata. 
$25^{\text {th }}$ October 2018 with an obelisk inauguration. The author reminiscenced the Founders, the 'Great Faculty' and the 'Masters', mentors and professors, who were not only contemporaries and friends of the institution but also holders of the two centuries' reputation. He made the point that the three Transdanubian campuses of Pannon University (Keszthely, Mosonmagyaróvár, Kaposvár) and the Szent István University (Gödöllö) collectively shared successes and memories in the historical successes of the European agricultural education and research.

Kulcsszavak: a "nagy tanári kar", „fénykorszak", magyaróvári felsőoktatás, bicentenárium, obeliszkavatás: a hűség és a tisztelet szimbóluma

Keywords: the "Great Faculty", "Golden Age", higher education at Magyaróvár, bicentenary, obelisk inauguration: symbol of faithfulness and respect

\section{BEVEZETÉS}

A Kolozsvári Egyetem rektora, Berde Áron (1819-1892), az MTA rendes tagja rektori székfoglalójában 1872-ben elhangzott gondolatai tükröződnek vissza Európa első agrár-felsőoktatási intézményeinek, a keszthelyi Georgikonnak és az óvári Gazdasági Felsőbb Tanintézetnek kétszáz évvel ezelőtti, történelmi időmércével mérve másodperci különbséggel elindult útján, amely remélhetöleg örök életü.

\section{A NAGY TANÁRI KAR ÉS A FÉNYKORSZAK}

A „nagy tanári kar” és a fénykorszak - amelyek elválaszthatatlanok egymástól tették nemzetközileg is híressé az óvári felsőoktatást. Magyaróvár sikerét annak köszönhette, hogy (1) nemzetközileg is elismert, széles látókörü professzorok vezették; (2) nemzetközi tapasztalatokkal, gazdag irodalmi munkásággal rendelkező, Európát „körbeutazó”, nyelveket beszélő „nagy tanári kar” alkotta; (3) a legkiválóbb hallgatókat (növendékeket) külföldre küldték tapasztalatszerzésre, hogy azt követően visszatérve Óváron katedrát foglaljanak el²; (4) olyan kultúr- és mezőgazdasági központokat - mai szóval kutatóhálózatot - hoztak létre, amelyek egyedülállóak voltak az Osztrák-Magyar Monarchiában, és amelyek megtermékenyítőleg hatottak nemcsak a magyar, hanem az európai agrároktatásra és agrár-

${ }^{2}$ A kutatva oktatás felső szintủ hangsúlyozására Pabst Henrik Vilmos, az óvári intézmény igazgatója (1850-1861) részben saját kérésre, részben meghívás alapján olyan, már nemzetközi hírnévvel rendelkező professzorokat hívott meg Óvárra, akik közül korábban többen is Óváron végezték tanulmányaikat. Így került Óvárra a nemzetközileg is jól ismert Sporzon Pál (1831-1919) a keszthelyi Georgikon Kar igazgatói székéből, Deininger Imre (1824-1918) a debreceni tanintézetből vagy Linhart György (1844-1925) Oroszországból, ahol Heléna Pavlova hercegnő tiszttartója volt, és akit 1874-ben az óvári tanintézet tanárává neveztek ki. 
kutatásra; (5) nem utolsósorban ebben a sikertörténetben az egyes intézmények nemcsak lokális érdekeket szolgáltak, hanem a három felsőoktatási intézmény (Keszthely, Magyaróvár, Debrecen) között olyan oktatási-kutatási szimbiózis alakult ki, amelynek hatása mindhárom intézményt Európa élvonalába helyezte.

\section{AZ ALAPÍTÓK ÉS AZ ELŐDÖK}

A kétszáz éves múltra tekintettel ki kell emelni Albert Kázmér (1738-1822) szász-tescheni királyi herceget az Óvári Gazdaságbéli Intézet megalapítóját, aki Liebbald Gyulát (1780-1846) a keszthelyi Georgikon nagy tapasztalatokkal rendelkező tanárát Óvárra hívta 1818-ban, hogy segítségére legyen Wittmann Gyulának (1770-1842) az intézmény létrejöttében és az első tanterv kidolgozásában.

A kétszáz éves Magyaróvári Felsőoktatás Ünnepén - amely az ünnepet ünneppé tevő elődeink sokaságáról, a jelet hagyókról szól - emlékeztetni szeretnék Ipolyi Arnold (1823-1886) teológusra, az MTA rendes tagjára, aki 1860-ban megtartott székfoglaló előadásában a következőket mondta: „Örizzük emlékeinket, gyüjtsük össze töredékeiket, nehogy végleg elvesszenek, s ezáltal is üresebb legyen a múlt, szegényebb a jelen, s kétesebb a jövő.” A teljességre törekvés nélkül szeretnék megemlékezni azokról az óvári és keszthelyi tanárokról, akik Óvárt és Keszthelyt naggyá tették, és személyiségükkel Óvárt és Keszthelyt is nemesítették. Mindenekelőtt Balás Árpádot (1844-1896) említem, akit 1844. szeptember 24-én a keszthelyi Georgikonból helyeztek át az óvári intézmény igazgatói székébe. Ö lett az óvári akadémia első igazgatója. A teljeségre törekvés nélkül, időrendi sorrendben megemlítem még Schandl János (1845-1913), Hensch Árpád (1847-1913), Cselkó István (1847-1930), Kosutány Tamás (1848-1915), Cserháti Sándor (1852-1909), Mezey Gyula (1861-1922), Ujhelyi Imre (1866-1923), Ejury Lajos (1870-1965), Rázsó Imre (1873-1922), Doby Géza (1877-1968), Juhos Lajos (1879-1940), Deininger Imre (1884-1918), Csiki László (1897-1988), Kolbai Károly (1901-1972), Dőry Lajos (1904-1977), Dohy János (1905-1990) profeszszorok nevét, akiknek a hazai felsőoktatás és kutatás történetében kiemelkedő szerepük volt.

A nagy elődök közül, akik talán a legnagyobb hatást gyakorolták rám, szeretném megemlíteni Horváth Géza (1847-1937) zoológust, az MTA rendes tagját, valamint Linhart György (1844-1925) és Cserháti Sándor (1852-1909) fitopatológusokat. Nem azért emelem ki öket a nagy elődök közül, mert a Magyar Növényvédelmi Társaság legnagyobb elismeréseit legméltóbban a Horváth Géza-emlékérem és a Linhart György-emlékérem adományozásával fejezi ki, hanem azért, mert a Horváth Géza az általa 1880-ban megszervezett Országos Phylloxera Kisérleti Állomást, 1890-től a Magyar Királyi Állami Rovartani Állomás vezetöje volt. Linhart György és Cserháti Sándor pedig az 1897-ben Óváron megszervezett 
első Vetőmagvizsgáló, Növényélettani és Kórtani Állomás vezetői voltak. Ezek az intézmények a jogelődjei a mai martonvásári MTA Agrártudományi Kutatóközpont budapesti Növényvédelmi Intézetének, egyetemeink növényvédelmi, rovartani és növénykórtani tanszékeinek, amelyekkel az elmúlt több mint hat évtizedben szoros szakmai és baráti kapcsolatban voltam. Részévé váltak életemnek, munkámnak, a rosszban bánataimnak, a jóban örömeimnek.

A keszthelyi és a mosonmagyaróvári Mezőgazdasági Akadémia újabb kori, a második világháború utáni történetében változást hozott 1945. szeptember 26-án az új budapesti Agrártudományi Egyetem felállítása (8740/1945. [X. 2.] ME rendelet), amely az intézményt négy karra, s azon belül a Mezőgazdaságtudományi Kart négy osztályba tagolta. A vidéki osztályok közül a mosonmagyaróvári osztály 1943-ban, a keszthelyi és a debreceni osztályok 1945-ben váltak akadémiából főiskolává. A rektori teendőket Doby Géza professzor látta el (1945-1947). Több professzor (Kuthy Sándor [1904-1970], Keller Oszkár [1882-1955], Kolbai Károly [1901-1972], Doby Géza [1877-1968], Horn Artúr [1911-2003], Schandl József [1845-1913], Csiki László [1897-1988]) Budapestre került korábbi tanszéküknek megfelelő katedrára, mások pedig (például: Berke Péter [1899-1982], Vladár Endre [1888-1967], Kulin Sándor [1904-1994], Szekeres Vince [18871976]) rendelkezési állományba kerültek.

Az 1949-ben megszünt Agrártudományi Egyetem professzorai közül többen Keszthelyen és Mosonmagyaróváron folytatták munkájukat. 1954-ben az újjáalakult keszthelyi Georgikonban - amelynek tanítványa voltam -, olyan kiemelkedő professzorokkal ismerkedhettem meg, akik Óváron is tanítottak: Vladár Endre (1888-1967), Berke Péter (1899-1982), Berzsenyi-Janosits László (1903-1982), Csiki László (1897-1988), Dohy János (1905-1990), Dőry Lajos (1904-1977), Láng Géza (1916-1980), Kemenesy Ernő (1891-1985), Kulin Sándor (1904-1994) és mások.

\section{A TUDOMÁNYOS EGYÜTTMÜKÖDÉS KEZDETEI ÉS A FOLYTATÁS}

A kétszáz éves óvári felsőoktatás ünnepén szeretnék megemlékezni Barsy Sarolta (1903-1980) Kossuth-díjas burgonyanemesítőről, aki 1933-ban első női hallgatóként szerzett diplomát az Óvári Gazdasági Akadémián. Tudományos pályafutásom - amely a keszthelyi Délnyugat-Dunántúli Mezőgazdasági Kísérleti Intézetben kezdődött el 1957. december 1-én, és a keszthelyi Mezőgazdasági Akadémián folytatódott - kezdetén ismertem meg Barsy Saroltát, aki 1951 óta a Somogy megyei Mariettapusztán végzett burgonyanemesítést. Hálás vagyok a sorsnak, hogy fiatalon megismerhettem őt, aki szerénységgel párosult tudással, a mostoha kutatási körülmények ellenére is optimista lényével, emberszeretetével ajándékozott meg. Öröm volt vele dolgozni, mert igényelte azokat az újabb ismereteket, 
amelyek a vírusrezisztencia kutatásban világszerte prioritást élveztek. Az általa nemesített vírusrezisztens burgonyafajták, amelyek elő́llításában együtt dolgoztunk, emlékeztetnek a jó együttműködésre. Ezt a tudományos együttműködést tekintem az első tudományos, mosonmagyaróvári kapcsolatnak, amely idestova hat évtizedre tekint vissza. A mai napon szeretettel emlékezem Barsy Saroltára, az együtt eltöltött időre és emlékekre, és arra a szomorú napra, amikor 1980-ban utolsó útjára kísértük a mosonmagyaróvári temetőben.

Az 1960-as években szoros szakmai kapcsolat alakult ki a Mosonmagyaróvári Főiskolán Kuroli Gézával (1936-2016), aki később 1972 és 2003 között a Növényvédelmi Tanszék vezetője, majd 1970-ben az egyetemmé vált intézmény (Agrártudományi Egyetem [Keszthely], Mosonmagyaróvári Mezőgazdaságtudományi Kar) rektorhelyettese és dékánja lett. Tudományos együttmüködésünk a burgonyavírusok, a levéltetủ vektorok és a vírusok epidemiológiai tanulmányozására terjedt ki. Szakmai és baráti kapcsolataink 1970 után tovább erösödtek a keszthelyi és a mosonmagyaróvári egyetemi karok, majd a Kaposvári Egyetem Állattenyésztési Karának 1987-ben történő integrációját követően az új elnevezésủ Pannon Egyetemen (Keszthely). Ez a kapcsolat akkor sem szünt meg, amikor 2000-ben a mosonmagyaróvári kart a Nyugat-magyarországi Egyetemhez (Sopron) integrálták. A kapcsolat akkor is folytatódott, amikor a magyaróvári mezögazdasági felsőoktatási intézmény kivált a Nyugat-magyarországi Egyetemből, és 2016. január 1-én Mezőgazdaság- és Élelmiszertudományi Kar néven csatlakozott a győri Széchenyi István Egyetemhez.

A mosonmagyaróvári együttmüködésben hajtóerő volt Linhart György, Mezey Gyula, Francé Raoul (Francé Rezső, 1874-1943) fényes szakmai múltja, akik megteremtették Mosonmagyaróváron az agrár-felsőoktatást és víruskutatást. A bölcső szelleme nagy hatással volt rám. A keszthelyi és mosonmagyaróvári szakmai és emberi kapcsolatok eredményeképpen több közös tudományos dolgozatunk jelent meg, és társszerzők voltunk az 1997-ben megjelent Növényvédelem (Bozsik et al., 1997) címü egyetemi tankönyvben is. Több mint fél évszázados együttmüködésünk során a Kari és Egyetemi Tanácsban, az MTA-MÉM Növényvédelmi Szakbizottságában, a Magyar Növényvédelmi Társaságban, az MTA Növényvédelmi Tudományos Bizottságban, a Veszprémi Akadémiai Bizottságban (VEAB) vezető pozíciókban szolgáltuk a mosonmagyaróvári, a keszthelyi egyetemi karok és a magyarországi növényvédelem érdekeit. Együttmüködésünk kiterjedt az aspiránsképzésre, a doktori iskolák vezetőiként pedig hozzájárultunk az egyetemi doktori képzéséhez (PhD). 2000 és 2007 között részt vettem a mosonmagyaróvári kar posztgraduális (növényvédelmi szakmérnöki szak) képzésében a virológia, fitoplazmatológia, szántóföldi növénybetegségek és növényvédelem tárgyak oktatásában, diplomadolgozatok irányításában, bírálatában és a vizsgáztatásban. Ebben az időben jelent meg a Növényvirológia (1999) címủ egyetemi jegyzetem és a társszerzőkkel írt Részletes növénykórtan 
(1993), A szántóföldi növények betegségei (1995) és a Növényvédelmi, növényorvosi alapismeretek (2004) címü egyetemi tankönyvek, amelyet többek között a mosonmagyaróvári egyetem entomológus professzora, Kuroli Géza és herbológus professzora, Reisinger Péter lektorált. A két utóbbi könyv a mai napig alapmü az agrár-felsőoktatásban. Kuroli Gézát kandidátusi értekezésének (1972. október 23.) és akadémiai doktori értekezésének (1994. november 3.) elkészítésében segítettem, és értekezéseinek megvédése során opponense, illetve bírálóbizottságának tagja voltam. Sáringer Gyulával a Magyar Tudományos Akadémia tagjaiként 2006. március 28-án Kuroli Gézát Eötvös-koszorú odaítélésére, és 2007. január 2-án Akadémiai-díjra javasoltuk.

Kuroli Géza professzort 2006. október 20-án, 70. születésnapján köszöntve a következőket mondtam: „Boldog vagyok azért, hogy nemcsak kortársad, egyetemi kollégád és barátod lehettem, hanem azért is, mert példát mutattál arra, amire küldetést kaptál a Teremtőtől." A nyolcvanadik születésnapját Kuroli Géza már nem élhette meg. 2016. augusztus 24-én az Óvári Akadémia „önzetlen építője” elhunyt, és a velem fennálló több mint fél évszázados kapcsolata örökre megszakadt.

Szoros szakmai kapcsolatban voltam a mosonmagyaróvári kar Kertészeti Tanszékével, Nagy György (1926-2008) tanszékvezető egyetemi tanárral is a csillagtök (patisszon) honosításával és a „különleges tökfélék” vírusfogékonyságának és vírusrezisztenciájának vizsgálatával kapcsolatban. A kutatási együttműködés, amely közös publikációkban nyilvánult meg, alapját képezte Nagy György professzor 1990-ben írt akadémiai doktori értekezésének.

1977-ben ismerkedtem meg a velem egykorú Czimber Gyula (1936-2008) egyetemi tanárral a mosonmagyaróvári kar Növénytani és Növényélettani Tanszék vezetöjével. Együttmüködésünk a növényidentifikálásban, a növények és a vírusok közötti kapcsolatok megismerésében, az MTA bizottságaiban és a VEAB-ban, valamint az Európai Gyomkutató Társaságban (European Weed Research Society) végzett közös munkánkban nyilvánult meg. A több mint három évtizedes szakmai és baráti kapcsolatunknak Czimber Gyula 2008. december 30 -án bekövetkezett váratlan halála vetett végett. 2009. január 7-én vettünk tőle végső búcsút a mosonmagyaróvári Feketeerdei-úti temetőben.

A megemlítendők között nem hagyhatom figyelmen kívül, hogy oktatási-tudományos tevékenységemben fontos szerepe volt Dohy János (1905-1990) magyaróvári professzornak is, aki az 1944/45-ös években a keszthelyi Mezőgazdasági Akadémia Növénytani és Állattani Tanszékének vezetője, majd 1954-től a mosonmagyaróvári Akadémia tanára volt. Keszthelyi tartózkodásának rövid ideje alatt családi kapcsolat alakult ki a Dohy és a Horváth család között. Ebben összekötö szerepet játszottak a két család egykorú fiai, akik később az MTA tagjai lettek. Dohy János professzorral - akit koholt vádakkal az 1956-os forradalom és szabadságharc leverése után tíz évre ítéltek - 1963-ban találkoztam újból (kegyelem- 
mel történt szabadulása után), amikor Dohy professzor felvételt nyert a keszthelyi Agrártudományi Főiskolára, és nem sokkal később a budapesti Növényvédelmi Kutató Intézet keszthelyi laboratóriumába, ahol együtt dolgoztunk növénykórtani, főleg burgonyakórtani és virológiai témákban. Kiemelkedő botanikai, növénykórtani ismereteit, emberségét és a fiatalság szeretetét ôrzöm róla emlékeimben.

Az utóbbi évek együttmüködései közül szeretném kiemelni Reisinger Péterrel, a mosonmagyaróvári kar tanszékvezető egyetemi tanárával kapcsolatos közös oktatási és szerkesztőbizottsági tevékenységet és a 2000-ben Mosonmagyaróváron közösen alapított Magyar Gyomkutatás és Technológia címü tudományos folyóiratot, amely fontos szerepet tölt be a hazai herbológusok, botanikusok, növényvédő szakemberek és PhD-hallgatók tudományos eredményeinek közlésében.

Szakmai, tudománypolitikai és emberbaráti szempontból büszke vagyok arra, hogy a mosonmagyaróvári egyetemi kar két eminens professzorának, Schmidt Jánosnak 2001-ben és Neményi Miklósnak 2010-ben történő akadémikussá jelölésében részt vehettem. Személyes találkozásaink azóta igazi ünnepnapok, amelyek összekötik a múltat a jelennel és a féltve őrzött jövővel.

Az egyetemi névváltozások, integrációk és több együttmüködő professzortárs elvesztése ellenére jó kapcsolat van a kilencedik nemzedéket nevelő keszthelyi és mosonmagyaróvári egyetemi intézmények jelenlegi munkatársaival, nem feledve a több mint két évszázados hírnév és közös értékek megőrzését.

\section{VÉGSZÓ ÉS KÖSZÖNET}

A 200 éves Magyaróvári Felsőoktatás Ünnepén emlékezem arra is, hogy a három „kari testvér” (Keszthely, Mosonmagyaróvár, Kaposvár) alkotta egykori Pannon Egyetem sikereiben osztozva közösek az emlékeink. Olyan tudóstársaságban éltem és dolgoztam, amely hosszú életem során örömmel és boldogsággal töltött el.

Köszönetet mondok azért, hogy pályafutásom és életem végéhez közeledve a Kaposvári Egyetem 2005-ben, a győri Széchenyi István Egyetem, Mezőgazdaság- és Élelmiszertudományi Kar (Mosonmagyaróvár) 2018-ban, a gödöllői Szent István Egyetem pedig 2019-ben Doctor honoris causa címmel tüntetett ki. Azt gondolom, hogy ezekben az elismerésekben a jó oktatási-kutatási együttmüködés és a példás emberbaráti kapcsolatok voltak a meghatározóak. Nem látok semmi okot a kitüntetésemre, mint ahogy a szem sem kap köszönetet azért, mert lát (bár egyre homályosabban), a fül sem azért, mert hall (egyre halkabban), a láb sem azért, mert jár (bár már nagyon ingatag), a szív sem kap köszönetet azért, mert mozgásban tart (bár dobbanása egyre gyengébb), és a gerinc sem azért, mert tartást ad (bár egyre görnyed). Csak dolgoztam, tettem a dolgomat, amelynek során a Gondviselés öt alapvető dologgal ajándékozott meg: ezek a szerencse, az inspiráció, az eltökéltség, az alázat és az emberbaráti szeretet. Ma is vallom, miként 
arra Pléh Csaba, az MTA rendes tagja, korábbi főtitkára rámutatott $A$ tudomány szabadsága a pénz világában címú munkájában, hogy a tudósvilágban a legfóbb mozgatóerő nem a társadalmi elismertség, nem a népszerüség, nem a kilépés a tömegközlés világába, hanem a szigorú belső világ általi elismerés. Ezért tekintem ezt a napot tudományos és oktatói pályám legméltóbb sorstársi, egyetemi elismerésének.

\section{IRODALOM}

Belák S.- Csiki L. - Füzes M. et al. (1972): Georgikon 175. Budapest: Mezőgazdasági Kiadó

Bognár S. (1993): Mosonmagyaróvár és a magyar növényvédelem kapcsolata. Acta Ovariensis, 35, 259-268.

Bozsik A. - Bujáki G. - Bürgés Gy. et al. (1997): Növényvédelem. Budapest: Mezőgazda Kiadó

Czimber Gy. - Horváth K. (1993): A tanszékek és egységek története (1954-1993). Mosonmagyaróvár: Pannon Agrártudományi Egyetem, Mezőgazdaságtudományi Kar

Cser J. (2018): GazdászBiblia. Mosonmagyaróvár: Óvári Gazdászok Szövetsége Egyesület

Dudits D. (1993): Szemelvények a mosonmagyaróvári mezögazdasági felsőoktatás történetéböl. Mosonmagyaróvár

Fehér Gy. - Kurucz Gy. - Zsidi V. (1996): Georgikon 200. Emlékkönyv a Georgikon alapitásának 200. évfordulójára. Keszthely: Pannon Egyetem

Fülöp É. M. (1996): Georgikon 200. Keszthely: Pannon Agrártudományi Egyetem

Horváth J. (2005): A Herman Ottó úti szellem: Valóság és misztérium. Növényvédelem, 41, 571-573.

Horváth J. (2007): Quo vadis agrártudomány. Növényvédelem, 43, 211-213.

Horváth J. (2008): Gondolatok az agrártudományról, az agrároktatásról és az értelmiség felelősségéröl. Növényvédelem, 44, 247-254.

Horváth J. (2012a): A növekedés és a csökkenés dilemmái. 1. Történeti áttekintés: A magyar növényvédelem alapjainak lerakása. Növényvédelem, 48, 123-129.

Horváth J. (2012b): A növekedés és a csökkenés dilemmái. 2. A növényvédelem próbatételei és a 20. század történelmi viharai. Növényvédelem, 48, 177-181.

Horváth J. (2012c): A növekedés és a csökkenés dilemmái. 3. Növényvédelmi oktatást és kutatást végző 20. századi és 21. század eleji intézmények Magyarországon. Növényvédelem, 48, 282-293.

Horváth J. (2012d): A növekedés és a csökkenés dilemmái. 4. A növényvédelmi szervezet és a szakigazgatás. Növényvédelem, 48, 329-339.

Horváth J. (2013): A tudásalapú társadalom építőkövei: Oktatás, kutatás, szakigazgatás, innováció. Növényvédelem, 49, 171-177.

Kuroli G. (2007): A hazai agrár-felsőoktatás bölcsője. Növényvédelem, 43, 495-505.

Németh A. (2009): Biographiae Óvariensis. 1. Válogatott életrajzok a magyaróvári agrárfelsőoktatás 190 éves történetéből 1818-2008. Mosonmagyaróvár: Óvári Gazdászok Szövetsége

Pléh Cs. (2006): A tudomány szabadsága a pénz világában. Magyar Tudomány, 167, 7, 879-885.

Pör Cs. - Zsidi V (2008): Magyar Királyi Gazdasági Akadémia 1906-1945. Keszthely: Pannon Egyetem Georgikon Mezőgazdaságtudományi Kar

Reisinger P. (2016): Kuroli Géza 1936-2016. Növényvédelem, 77, 52, 9, 477-478. 
Rosta I. (2011): A Kaposvári Egyetem története a kezdetektöl 2011-ig. Kaposvár: Kaposvári Egyetem

Szabó I. (2006): Tanulmányok, emlékezések és köszöntök 1. Tudomány történeti füzetek. (Georgikon Kiskönyvtár) Keszthely: 20, 1-219.

Takács A. P. - Várnagy L. (2012): Pannon Egyetem Georgikon Kar Növényvédelmi Intézetének története (1972-2012). Keszthely: Pannon Egyetem

Tenk A. (2017): Dicsö múltunk 1. A Magyaróvári Gazdasági Akadémia XIX. századi fénykorszaka és nagy tanári kara (1818-1918). Győr: Tarandus Kiadó

Tenk A. (2018): Dicső múltunk 2. A magyaróvári agrárfelsőoktatás második 100 éve. A nagy átalakulások évszázada (1918-2018). Győr: Tarandus Kiadó

Walleshausen Gy. (1993a): A magyaróvári felsőoktatás 175 éve. Mosonmagyaróvár: Pannon Agrártudományi Egyetem Mosonmagyaróvári Kar

Walleshausen Gy. (1993b): A magyaróvári felsőoktatás 175 éve. Képmelléklet. Mosonmagyaróvár: Pannon Agrártudományi Egyetem Mezőgazdaságtudományi Kar

Walleshausen Gy. (1995): A gödöllöi Agrártudományi Egyetem jubileumi emlékkönyve (19201995) I-II. Gödöllő: Gödöllői Agrártudományi Egyetem 